УДК 342.41

DOI https://doi.org/10.32837/pyuv.v0i5(34).643

\author{
Г. В. Берченко \\ orcid.org/0000-0002-0365-9009 \\ кандидат юридичних наук, доцент, \\ доцент кафедри конституиійного права України \\ Національного юридичного університету ілені Ярослава Мудрого
}

\title{
ПРЕАМБУЛА КОНСТИТУЦІЇ: ЮРИДИЧНА ПРИРОДА ТА ПРАКТИКА ВНЕСЕННЯ ЗМІН
}

Яка юридична сила преамбули конституції? Чи має вона нормативний характер? Чи можна вносити зміни до преамбули? Ці та інші питання, пов’язані з преамбулою Конституції України, час від часу порушуються на практиці. Відповіді на них були б недостатньо обгрунтованими без доктринального осмислення зарубіжного досвіду і застосування порівняльно-правового методу.

Метою статті є з'ясування юридичної природи преамбули конституції та практики внесення до неї змін. Завданнями статті є: розкрити юридичну природу преамбули конституції; з'ясувати процедурні аспекти та практику внесення змін до преамбули конституції в зарубіжних країнах; 3'ясувати практику та юридичні наслідки внесення змін до преамбули Конституції України.

Текстуально преамбули можуть мати різне викладення. Певні положення можуть навіть передувати преамбулі. Ілюстрацією слугує іспанська конституція, що починається зі слів «Дон Хуан Карлос I, Король Іспанії, всім, хто побачить і зрозуміє цей Акт. Знайте, що Кортеси схвалили, а іспанський народ затвердив цю Конституцію:», після чого розміщена «Преамбула» [1, с. 3-4]. Багато сучасних конституцій (Австрія, Бельгія, Данія, Ісландія, Італія, більшість країн Латинської Америки) не мають преамбули, але загальна тенденція все-таки зводиться до того, що новітні конституції мають преамбулу [2, с. 40].

Передусім дискусійним є нормативний характер преамбули. Чи має преамбула в юридичному сенсі конституційне значення? Двічі депутат Дежан (член Консультативного конституційного комітету Франції) ставив це питання, а урядовий комісар Р. Ж゚ано незмінно відповідав: «Ні, категорично ні». Вочевидь, таким і був намір упорядників конституції, проте ніщо в цьому документі не дозволяє заперечувати юридичне значення і цінність преамбули [3, с. 30]. Свідченням останнього є те, що практика Конституційної Ради згодом пішла саме таким шляхом.

Як зазначає А.О. Мішин, преамбула зазвичай містить у собі урочисту формулу проголошення конституції, цілі прийняття конституції, посилання на колишню конституцію і деякі інші документи. За загальним правилом, преамбула, хоча вона і $€$ інтегральною частиною конституційного тексту, не має нормативного характеру.
Ïї положення вважаються суто декларативними, за винятком тих, які є відсильними нормами (див. Преамбули до конституції Франції, Республіки Кот-д’Івуар) [2, с. 40].

I.I. Пляхимович стверджує, що преамбула конституції Білорусі не містить норм права, проте іï варто використовувати для з'ясування змісту основного конституційного тексту. У цьому зв'язку Конституцію необхідно розглядати в єдності всіх її положень [1, с. 5].

На думку Й. Ізензее, завдання преамбули Основного Закону - визначити принципове співвідношення держави і конституції. Вступна частина, не зачіпаючи позитивно-правової матерії конституційного регулювання, вказує на підстави їі авторитетності, що лежать поза правом, а також витоки конституційної правотворчості. Конституцієдавець декларує легітимність і усвідомленість своїх дій, проголошує моральні підстави своєї відповідальності, визначає свої цілі і встановлює юридичні гарантії [4, с. 6]. Згідно з практикою Федерального Конституційного Суду преамбулі Основного закону ФРН притаманне передусім політичне, але, попри це, і безпосередньо юридичне значення [5, с. 95].

Передусім преамбула є потенційним джерелом безпосереднього забезпечення виконання права. Зазвичай преамбули не піднімаються вище рівня моральних апеляцій, не передбачаючи негайних юридичних зобов'язань. Однак у деяких випадках права можуть бути виведені безпосередньо з самої преамбули. Це, звичайно, передбачає, що преамбула є невід'ємною частиною конституції. У ряді преамбул прямо зазначено, що це саме так [6, с. 89].

Містячи основні цінності та принципи, на які спирається конституція, преамбула може також забезпечити конституційні органи рамками для тлумачення. Преамбули задають тон подальшому конституційному тексту. Таким чином, вони можуть слугувати орієнтиром для інтерпретації конституційного тексту. Преамбула також може сприяти тому, що німці називають єдністю конституції (Einheit der Verfassung). Цей принцип вимагає, щоб німецьку конституцію, Основний закон, читали та тлумачили як єдине ціле: жодна стаття не повинна тлумачитися окремо. Принцип єдності конституції слугує для вирішення 
можливих суперечностей або напруженості всередині конституції [6, с. 90].

Нарешті, преамбула може також слугувати конституційному закріпленню. Цінності, принципи та права, записані в преамбулі, можуть вважатися такими, що мають вищу юридичну цінність, таким чином, що вони виключають поправки до конституції, які суперечать їм. У цьому разі преамбула визначає межі установчої влади. Наприклад, стаття 7В конституції Бангладеш забороняє поправки, що змінюють преамбулу або пронумеровані статті, що стосуються «базової структури» конституції. Подібним чином стаття 141 (3) конституції Непалу забороняє реєструвати політичні партії, що порушують «основний дух і суть Преамбули». Це положення, щоб бути ефективним, вимагає критерію або доктрини, які визначають, що, звичайно, вважається «основним духом та суттю Преамбули» [6, с. 91].

Унікальним у своєму роді є досвід Франції, де сформувалася так звана доктрина конституційного блоку (bloc de constitutionnalit - фp.). Ця доктрина завдячує своїй появі практиці Конституційної Ради Франції на підставі Конституції V Республіки 1958 року. До конституційного блоку належить Декларація прав людини і громадянина 1789 р., Преамбула до Конституції 1946 р., основні принципи, визнані законами Республіки (згадуються саме в такому формулюванні в преамбулі до Конституції 1946 р.), а також Екологічна хартія 2004 року, вписана в преамбулу Конституції 1958 року конституційним законом від 1 березня 2005 р.

Термін «конституційний блок» напряму використовується Конституційною Радою в своïx рішеннях (дивіться, наприклад, рішення n 85-204 DC від 16 січня 1986 р.). Спершу рішення Конституційної Ради n 71-44 DC, прийняте 16 липня 1971 р., встановило свободу асоціацій серед основоположних принципів, визнаних законами Республіки, згаданими в преамбулі Конституції 1946 року і «урочисто підтвердженими» Конституцією від 4 жовтня 1958 року. Оскільки закон 1901 року, що передбачав свободу об'єднання, був таким «республіканським» законом, захищав свободу асоціацій, така свобода повинна мати і конституційний статус. Таким чином, відбулася «Революція прав», за якою Конституційна рада перетворила "незначну» преамбулу 1958 року на «матрьошку», відкривши майже безмежні конституційні ресурси [7, с. 5]. Декларація прав людини та громадянина, на яку посилається преамбула до Конституції 1958 року, офіційно увійшла до конституційного блоку внаслідок рішення про оподаткування n 73-51 від 27 грудня 1973 року (стосовно принципу рівності).

Доктрина конституційного блоку також знайшла своє втілення в юриспруденції Конституційного Суду Молдови. В постанові від 5 грудня
2013 р. № 36 про тлумачення частини 1 статті 13 Конституції у співвідношенні з Преамбулою Конституції і Декларації про незалежність Республіки Молдова Конституційний Суд Республіки Молдова вирішив, що конституційний характер має не лише Конституція, але й інші основоположні акти [8, с. 76].

Щодо України, то виникає питання про конституційний характер Акту проголошення незалежності України, який згаданий в преамбулі Конституції України, а також щодо статусу Декларації про державний суверенітет України, яка згадується в Акті. Проте офіційно жодного разу доктрина конституційного блоку в Україні не проголошувалася.

Виникає питання щодо нормативності і юридичної сили преамбули Конституції України. Під час обговорення проекту Конституції України була дискусія щодо природи преамбули. Ф. Бурчак наголошував, що вона має нормативний характер, a I. Заєць заперечував [9, с. 39]. Як стверджує M.I. Козюбра, як і інші положення Конституції, положення ï преамбули мають нормативний характер, хоча їх нормативність виражена в найзагальнішій формі. Інша справа, що механізм реалізації положень преамбули має істотні особливості порівняно з іншими положеннями Конституції. Преамбули насамперед є орієнтиром у практичній діяльності державних органів і органів місцевого самоврядування, об'єднань громадян, посадових і службових осіб та громадян, визначає загальну лінію правотворчої діяльності, вказує стратегічний напрям конституційного і нормативно-правового регулювання в цілому [10, с. 6$]$.

Свого часу преамбула Конституції відіграла велику роль для позиціювання Конституції України як акта установчої влади. У рішенні від 11 липня 1997 року № 3-зп Конституційний Суд України (далі - КСУ) зазначив, що «прийняття Конституції України Верховною Радою України було безпосереднім актом реалізації суверенітету народу, який тільки одноразово уповноважив Верховну Раду України на її прийняття». Зв'язок Конституції України з концепцією установчої влади став можливим завдяки преамбулі, в якій йдеться про прийняття Конституції парламентом від імені Українського народу. Опосередкування суверенної волі народу під час прийняття Конституції 28 червня 1996 року КСУ підтвердив з посиланням на преамбулу і в п. 4.1, 4.3 мотивувальної частини рішення від № 6-рп/2005 від 5 жовтня 2005 року (справа про здійснення влади народом).

У абз. 3 п. 3.1.1 висновку від 13 листопада 2019 року № 5-в/2019 КСУ, висловлюючи застереження до законопроекту (щодо законодавчої ініціативи народу), звернувся до тлумачення поняття «народ» виходячи 3 його визначення у преамбулі - «Український народ - громадяни 
України всіх національностей». Преамбула згадувалася і при тлумаченні поняття «юридична відповідальність» (абз.2 п.2 мотивувальної частини рішення КСУ № 7-рп/2001 від 30 травня 2001 року (справа про відповідальність юридичних осіб)). Проблема нормативного характеру преамбули постала знов у зв'язку із конституційним поданням 142 народних депутатів України № 3/172(20) від 05 травня 2020 р. щодо офіційного тлумачення положень абзацу четвертого преамбули Конституції України у їх системному зв'язку з положеннями частини другої статті 3 , частини четвертої статті 13, частини п'ятої статті 17 Конституції України, проте рішення ще не ухвалено.

Вартим уваги є також питання щодо внесення змін до преамбули конституції. Більшість конституцій залишаються мовчазними щодо питання внесення змін до преамбули. Лише одна конституція прямо визначає, що внесення змін до преамбули конституції заборонено. Стаття 7В конституції Бангладеш, що має назву «Основні положення Конституції, що не підлягають поправкам», говорить: «Незважаючи на те, що закріплено у статті 142 Конституції [процедура внесення змін до Конституції], преамбула. ... та положення статей, що стосуються базової структури Конституції. ... не може бути змінено шляхом внесення, модифікації, заміни, скасування або будь-яким іншим способом». Це положення прямо вказує на неконституційність змін до конституції, які могли б змінити преамбулу [6, с. 99].

Деякі інші конституції, навпаки, містять положення про внесення змін до преамбули (Габон, Македонія). Загалом, здається, що преамбули можуть бути додані до конституції та вилучені 3 неї, як і пронумеровані положення основного тексту. Можлива зміна тексту преамбули. Однак у важливих аспектах преамбула відрізняється від пронумерованих положень конституції, що робить поправки менш імовірними. Преамбула передусім пишеться для нової конституції, яка своєю чергою зазвичай адаптується до переломного моменту в історії держави. Преамбула характеру “Clean break" («повний розрив» або «чистий аркуш») відкидає попередній конституційний режим і виправдовує новий, тоді як преамбула “de novo" повністю зосереджується на новому початку. Конституційні моменти, яким такіпреамбули дають вираження, є одноразовими: вони трапляються лише один раз. Таким чином, внесення змін до преамбули поза таким конституційним моментом є трохи дивним. Тим не менш, такі зміни відбуваються [6, с. 100].

Розглянемо декілька прикладів зміни преамбули. У 1976 році до Преамбули конституції Індії було внесено зміни (лише один раз до цього часу) 42-м Законом про внесення змін до Конституції. До Преамбули були додані нові характеристики держави (соціалістична, світська) та згадка про єдність нації. Спочатку Верховний Суд у справі Союзу Берубарі (1960, "Berubari Union case") постановив, що Преамбула не є частиною Конституції. Однак він визнав, що Преамбула може використовуватися як керівний принцип, якщо термін у будь-якій статті Конституції є неоднозначним або має більше одного значення. У справі Кесавананд Бхарті (1973 р., "Kesavanand Bharti case") Верховний Суд скасував своє попереднє рішення і визнав, що Преамбула є частиною Конституції і може бути змінена відповідно до статті 368 Конституції. Знову ж таки, у справі "LIC of India" Верховний Суд визнав, що Преамбула є частиною Конституції [11].

Досить «багатостраждальною» виявилася в цьому плані Конституція Австралії. В самому тексті конституції немає преамбули. Преамбула $є$ лише в Законі про конституцію Австралії 1900 р. Періодично виникають пропозиції щодо включення преамбули в текст конституції, проте існує жорстоке протистояння, зазвичай на основі змісту преамбули, а також можливих юридичних наслідків її тексту.

На суто символічному рівні видатні лідери корінних народів закликали в преамбулі Конституції визнати корінне населення першими жителями Австралії [12, с. 193]. Пропозиція про те, що конституція повинна отримати нову преамбулу на референдумі кілька разів, з'являлася за останні два десятиліття і піддавалася критиці з технічної точки зору обидва рази [13].

Як заявляв Республіканський консультативний комітет у 1993 році, варіанти преамбули такі: 1) видалити преамбулу; 2) залишити преамбулу як є; 3) залишити цю преамбулу такою, якою вона $\epsilon$, але додати нову преамбулу до самої Конституціï; і 4) оновити преамбулу. Процес зміни преамбули також ускладнений різними юридичними технічними умовами [14].

6 листопада 1999 року пропозиція щодо запровадження преамбули не була підтримана в ході референдуму, проведеного одночасно з референдумом щодо Республіки. Голосування «Так» (на користь включення преамбули) не досягло більшості в жодному з шести штатів. Конституція Австралії вимагає «подвійної більшості» на референдумі для затвердження поправки до конституції - більшість голосів серед штатів (тобто щонайменше чотирьох із шести) та більшість голосів всіх виборців.

Натомість Франція належить до країн, в яких успішно була змінена преамбула. В країні довго тривали широкі дебати на експертному рівні щодо різних пропозицій в частині зміни преамбули. Звіт комісії, поданий 17 грудня 2008 року Президентові Республіки, під головуванням колишнього міністра Симона Вейла у 2008 році, детально аналізує всі подані пропозиції [15]. Преамбула 
змінена у 2005 році законом від 1 березня, який стосувався введення в преамбулу посилання на Екологічну хартію і тим самим розширення переліку джерел «конституційного блоку» .

Конституційна рада послалася вперше на Екологічну хартію в Рішенні № 2005-514 DC від 28 квітня 2005 року (щодо створення Французького міжнародного регістру реєстрації суден). Конституційна рада встановила, що законодавець не знехтував принципом сталого розвитку, викладеним у статті 6 Екологічної хартії. У п. 18 рішення Конституційної ради Франції n 2008-564 DC від 19 червня 2008 р. щодо закону про «ГМО» стверджується, що «...всі права та обов’язки, визначені Екологічною хартією, мають конституційне значення; вони нав'язують себе органам державної влади та адміністративним органам у відповідних галузях своєї компетенції». Положення Екологічної хартії як конституційного джерела були застосовані Конституційною радою Франції також у рішеннях від 29 грудня 2009 р. № 2009-599 DC i n 2011-116 QРС від 8 квітня 2011 р.

Ці судові підтвердження свідчать про те, що будь-яке доповнення до преамбули супроводжується практичними наслідками і додає ще одне письмове джерело конституційних норм поряд 3 іншими [7, с. 15].

Латвія - ще одна країна, в якій була змінена преамбула до конституції. Варто нагадати їі історію. 4 травня 1990 року Верховна Рада Латвійської РСР проголосила відновлення незалежності Латвійської Республіки і відновлення дії конституції 1922 року (повністю конституція відновлена 6 липня 1993 року). Водночас Конституція Латвії 1922 року мала дуже коротку преамбулу. Нова преамбула була додана до конституції в 2014 році. Закон про це від 19 червня 2014 р. набув чинності 22 липня 2014 p.

Вдатися до зміни преамбули Основного Закону у зв'язку з об'єднанням у 1990 році була змушена також Федеративна Республіка Німеччина.

Щодо України, то Законом № 2680-VIII від 07.02.2019 р. абзац п'ятий преамбули був доповнений словами «підтверджуючи європейську ідентичність Українського народу і незворотність європейського та євроатлантичного курсу України». 3 точки зору процедури розділ XIII самої Конституції в плані внесення змін говорить в цілому про «Конституцію України», не виокремлюючи якось преамбулу, тому формально обмежень щодо її зміни не було. КСУ у висновку від 22 листопада 2018 року № 3-в/2018 жодних застережень щодо зміни преамбули не висловив. Водночас деякі судді в своїх окремих думках наголошували на тому, що преамбула Конституції України не може бути змінена (судді М. Гультай, О. Касмінін), об'єктивно неможливо змінити існуючі на той момент передумови, мотиви та цілі їі прийняття, запропоновані Законопроектом зміни до преамбули Конституції України однозначно стосуються засад зовнішньополітичної діяльності, а тому вони мали б вноситися до її статті 18, у якій вони знайшли б своє закріплення у відповідному формулюванні (суддя М. Мельник). О. Литвинов стверджував, що з огляду на основоположне значення преамбули як ціннісної основи Конституції України та фундаменту конституційного ладу в Україні ऑii зміна має бути схвалена Українським народом на всеукраїнському референдумі, тобто у формі безпосередньої, а не представницької демократії. На думку О. Тупицького, законопроектом зміна для внесення до тексту преамбули Основного Закону України хоча й не суперечить вимогам його статей 157,158 , проте фактично спотворить відображення у цій преамбулі історичної дійсності, за якої 28 червня 1996 року відбувалося прийняття Основного Закону України. Окрім того, суддя ставить питання і про формальну суперечність із Актом проголошення незалежності України, в якому згадується Декларація про державний суверенітет України (щодо наміру стати нейтральною державою).

Таким чином, можна зробити висновок, що преамбула кожної конституції (в разі її наявності) може відігравати різну роль у правовій системі в силу специфіки юридичної техніки. Звичайно, це не виключає певних науково-теоретичних узагальнень, проте все одно вони мають враховувати особливості національної конституційно-правової практики.

Зарубіжний досвід, хоч і в одиничних випадках, загалом демонструє принципову можливість внесення зміни до преамбули конституції. Інша справа, що кожен такий випадок був унікальним і зміни преамбули мали досить значуще обгрунтування через історичні причини (ФРН, Латвія) або вписувалися у вже існуючі доктринальні конструкції (Франція). При цьому, наприклад, Австралія, до сих пір не може вирішити проблему преамбули своєї конституції. Звичайно, вносячи зміни до преамбули, ми тим самим прямо чи опосередковано очікуємо певних нормативних наслідків таких змін. До речі, саме цей дискурс щодо нормативних наслідків і стримує довгий час Австралію від оновлення (створення) преамбули конституції. В Україні ж внесення змін преамбули Конституції відбулося відносно легко, хоча, звичайно, не всі судді КСУ, парламентарі і юристи підтримали цю ідею. При цьому до сих пір питання нормативного значення преамбули так достеменно і не з'ясовано.

\section{Jimepamypa}

1. Пляхимович И.И. Комментарий к Конституции Республики Беларусь : в 2 т. Минск : Амалфея, 2015. T. 1.1224 c. 
2. Мишин А. А. Конституционное (государственное) право зарубежных стран: Учебник. Москва : Белые альвы, 1996. 400 с.

3. Люшер $\Phi$. Конституционная защита прав и свобод личности. Москва : Изд. гр. «Прогресс» «Универс», 1993. 384 с.

4. Государственное право Германии: сокращенный перевод немецкого семитомного издания. Москва : Ин-т гос. и права РАН, 1994. Т. 1. 312 с.

5. Маунц Т. Государственное право Германии (ФРГ и ГДР). Москва : Изд-во иностр. лит., 1959. 596 с.

6. Voermans W., Stremler M., Cliteur P. ConstitutionalPreambles:AComparativeAnalysis. Massachusetts: Edward Elgar Publishing Limited, 2017. 302 p.

7. Granger M.-P. The Preamble(s) of the French Constitution: Content, Status, Uses and Amendment Acta Juridica Hungarica 52, No 1, pp. 1-18 (2011).

8. Шустров Д.Г. Пределы изменения конституции и конституционный контроль за их соблюдением в России и постсоветских государствах: сравнительно-правовое исследование. В 2-х томах. Том 2. Москва : Юрлитинформ, 2018. 568 с.

9. Стенограма засідання № 47 Робочої підкомісії Конституційної комісії України від 21 лютого 1996 р. Конституція незалежної України. У 3 кн. Кн. 3. Ч. 11. Київ : Укр. Правнича Фундація, 2010. С. 1-125.

10. Конституція України. Науково-практичний коментар / редкол.: В.Я. Тацій (голова редкол.), O.В. Петришин (відп.секретар), Ю.Г. Барабаш та ін. 2-ге вид., переробл. і допов. Харків : Право, 2011. 1128 c.

11. Hemant S. What is the Preamble of the Constitution of India? URL: https://www.jagranjosh.com/general-knowledge/ preamble-of-the-constitution-1434782225-1.

12. Harris B. A new constitution for Australia. London-Sydney : Cavendish Publishing Limited, 2002. $313 \mathrm{p}$

13. Pyke J. Reasons Not To Be Scared of a New Constitutional Preamble. URL: https://auspublaw.org/ 2016/05/reasons-not-to-be-scared/.

14. McKenna M. The Need for a New Preamble to the Australian Constitution and/or a Bill of Rights. URL: https://www.aph.gov.au/about parliament/ parliamentary departments/parliamentary library/ pubs/rp/rp9697/97rp12.

15. Comit de reflexion sur le perambule de la Constitution. Rapport au President de la Republique. URL: https://www.ladocumentationfrancaise.fr/var/ storage/rapports-publics/084000758.pdf

\section{Анотація}

Берченко Г. В. Преамбула конституції: юридична природа та практика внесення змін. - Стаття.

У статті з'ясовано юридичну природу преамбули конституції та практику внесення до неї змін. Зроблено висновок про те, що преамбула кожної конституціі (в разі ї наявності) може відігравати різну роль в правовій системі в силу специфіки юридичної техніки. Звичайно, це не виключає певних науково-теоретичних узагальнень, проте все одно вони мають враховувати специфіку національної конституційно-правової практики. Зарубіжний досвід, хоч і в одиничних випадках, загалом демонструє принципову можливість внесення зміни до преамбули конституції. Інша справа, що кожен такий випадок був унікальним і зміни преамбули мали досить значуще обгрунтування або вписувалися у вже існуючі доктринальні конструкції. Так, у Франціі преамбула змінена у 2005 році законом від 1 березня, який стосувався введення в преамбулу посилання на Екологічну хартію, і тим самим було розширено перелік джерел «конституційного блоку». Успішним є досвід внесення змін до преамбули конституції в Індії, Латвії, ФРН. При цьому, наприклад, Австралія, до сих пір не може вирішити проблему преамбули свої конституції. Звичайно, вносячи зміни до преамбули, ми тим самим прямо чи опосередковано очікуємо певних нормативних наслідків таких змін. До речі, саме цей дискурс щодо нормативних наслідків і стримує довгий час Австралію від оновлення (створення) преамбули конституції. В Україні ж, за винятком окремих думок суддів Конституційного Суду України, зміни преамбули Конституції якогось особливого спротиву не зустріли. Законом № 2680-VIII від 07.02.2019 р. абзац п’ятий преамбули був доповнений словами «підтверджуючи європейську ідентичність Українського народу і незворотність європейського та євроатлантичного курсу України». Водночас питання нормативного значення преамбули так достеменно і не з'ясовано.

Ключові слова: преамбула, конституція, конституційний контроль, доктрина конституційного блоку, нормативність.

\section{Summary}

Berchenko $H$. V. Preamble to the constitution: the legal nature and practice of change. - Article.

The article clarifies the legal nature of the preamble of the constitution and the practice of amending it. It is concluded that the preamble of each constitution (if any) may play a different role in the legal system due to the specifics of legal techniques. Of course, this does not exclude certain scientific and theoretical generalizations, but still they must take into account the specifics of national constitutional and legal practice. Foreign experience, although in isolated cases, in general, demonstrates the fundamental possibility of amending the preamble of the constitution. Another thing is that each such case was unique and the changes to the preamble had a very significant justification or fit into existing doctrinal construction. Thus, in France, the preamble was amended in 2005 by a law of March 1, 2005, which included a reference to the Environmental Charter in the preamble and thus expanded the list of sources of the "constitutional bloc". The experience of amending the preamble of the constitution in India, Latvia and Germany has been successful. In this case, for example, Australia still cannot solve the problem of preamble to its constitution. Of course, by amending the preamble, we thereby, directly or indirectly, expect certain regulatory consequences of such changes. By the way, it is this discourse on regulatory consequences that has long deterred Australia from updating (creating) the preamble of the constitution. In Ukraine, with the exception of some opinions of judges of the Constitutional Court of Ukraine, changes to the preamble of the Constitution did not meet with any particular resistance. By Law № 2680-VIII of February 7, 2019, the fifth paragraph of the preamble was supplemented with the words "confirming the European identity of the Ukrainian people and the irreversibility of the European and Euro-Atlantic course of Ukraine". At the same time, the normative meaning of the preamble has not yet been clarified.

Key words: preamble, constitution, constitutional control, doctrine of the constitutional bloc, normativity. 